\title{
CO-INTEGRATION TEST OF SELECTED INDEXES ON THE SHARE MARKET AND INDEX OF HOUSING REAL ESTATE PRICES
}

\author{
Rafal Wolski \\ Faculty of Capital Market and Investments \\ University of Lodz \\ e-mail:rafal.wolski@uni.lodz.pl
}

\begin{abstract}
The integration of financial markets is an ongoing process throughout the world. Research shows that, from Australia through Europe to the United States, the capital and real estate markets are integrating, influencing each other. Although this process seems obvious, only research can show whether it actually occurs. Identifying these relationships is important for analyzing the entire market. Many methods, such as estimating the cost of equity, have been developed with the stock market in mind. Meanwhile, real estate valuation requires the cost of equity. Market integration is the rationale for using equity market methods on the real estate market.

Aim of the work - the research is aimed at verifying whether there is cointegration between the secondary housing market and the stock market. A research hypothesis was put forward: the stock market and secondary housing market are integrated.

Research methodology - the study used co-integration analysis using the Engle-Granger test. The study was conducted in the period from the third quarter of 2006 to the fourth quarter of 2018.

Result - The tests carried out showed the existence of co-integration in one out of 36 cases for the explanatory variable - the delayed WIG index and the explained variable in the average price of residential real estate on the secondary market for the 7 largest Polish cities.

Originality / Value - demonstrating the co-integration of markets justifies the use of analytical methods developed for stock markets on real estate markets. The research has no equivalent study on the Polish market. Similar analyses were carried out, but not for the stock and real estate market.
\end{abstract}

Key words: real estate market, stock market, co-integration test of stock and real estate, relationship between stock and real estate.

JEL Classification: G11, G17, R30, R31, R39.

Citation: Wolski, R. (2020). Co-Integration Test of Selected Indexes on the Share Market and Index of Housing Real Estate Prices. Real Estate Management and Valuation, 28(1), 100-111.

DOI: https://doi.org/10.1515/remav-2020-0009

\section{Introduction}

The integration of financial markets seems to be an obvious and commonly occurring phenomenon. Treating the economy as a group of connected vessels makes it possible to suspect that similar phenomena will also occur in the case of financial markets. Research confirms these trends. It was noted, for example, that the real estate market ceased to be a place where only housing needs were met, and became a place for investing capital (Coşkun, 2013). In addition, studies show a strong correlation of the real estate market with the condition of the economy, although this relationship varies over time, both in terms of strength and the direction of change (Foryś, 2012). The capital market is also closely related to the condition of the economy and is sometimes considered a barometer of economic sentiment. Reliable information, associated with high frequency of quotation 
updates, contributes to increased market transparency, thus increasing investment security (Wallace, 1996). The lack of relevant information on the Polish housing market may explain the limited demand on the demand side of investors treating real estate as a capital investment (Clayton, 2007; Wolski \& Zaleczna, 2013). The comparison of the real estate market and the capital market creates a need for research on market integration. Demonstrating ongoing integration can be useful for investors and analysts. The benefits may be improved real estate market transparency, which, like on the capital market, will increase investment security. Another benefit may be the legitimate extension of the range of methods explaining the state of the market. In particular, it is worth paying attention to the problem of estimating the cost of equity. Determining this cost is a requirement when applying profitable valuation methods for both companies and real estate. However, estimating the cost of equity on the real estate market is difficult. This cost is usually determined using the beta coefficient, which is a measure of systematic risk. These are issues related to the CAPM model (e.g. Jensen, 1968). This model was created for the needs of the stock market and uses stock indexes as a measure of the development of the entire market. However, these indexes do not contain information about changes in prices on the real estate market. If the real estate and equity markets showed no dependence, then the beta calculation could be negated. This problem has been known to researchers for a long time causing doubts that can arise from counting betas using the stock index, which does not include real estate prices (Voicu \& Seiler, 2013). Research on beta calculation for the real estate market has already been conducted and showed that systematic risk calculated using hedonic home price indices covers only the residential real estate segment, and that its information value is severely limited by the lack of comparisons with other investments (Wolski, 2014). Risk analysis is just one of the fields in which demonstration of market integration may apply. If the state of the stock market is reflected in the real estate market, one can imagine building a model forecasting the behavior of the real estate market. The construction of such a model could authenticate investment forecasts and increase the level of security of real estate investments (Wilson et al., 1996). This is important because the real estate market carries certain restrictions for investors that do not exist on the stock market. These restrictions include, for example, the lack of transaction transparency, lack of continuity of valuations, or incomparability of transaction items (Maclennan et al., 1998).

\section{Literature overview}

In the literature, many research works can be found on the relationship between real estate and stock markets. The methodology of these studies can be divided into two groups using correlation analysis and co-integration analysis. The undertaking analyses differ from one another in their approach to the topic, from the context of wealth effect, crowding-out effect or substitution effect to portfolio theory. The existence of these effects also explains the integration of both markets. However, one of the previous studies did not show any relationship between the markets. In the context of investment decisions, referring to the Arbitrage Pricing Model, Wilson et al. examined various asset portfolios by checking the degree of integration of property and equity markets in Australia. Statistically significant conclusions could not be drawn from the study, although, it seems that stocks and real estate cannot be included in the same asset class (WILSON et al., 1996). Okunev and Wilson conducted linear and nonlinear co-integration tests between real estate and equity markets. The REIT and the S\&P500 index were tested from January 1973 to December 1993. Linear tests did not lead to any results, but researchers showed that the relationship between these markets can be non-linear, showing partial market integration (OKUNEV \& WIISON, 1997). QUAN and TITMAN expanded real estate and stock market research to 17 countries. Positive correlation was found everywhere in the long run. The analysis also shows that real estate is an investment that effectively protects capital against the effects of inflation (QUAN \& TITMAN, 1999). OKUNEV, WILSON and ZURBRUEGG conducted research on the Australian market. The study, carried out in the context of diversification of the investment portfolio, was conducted in terms of the relationship between the stock market and the real estate market, with the stock market represented by the oldest and widest Australian All Ordinaries stock price index, while real estate was represented by the real estate price index - real estate index. A relationship between the two markets was shown, demonstrating that price movements in both markets were delayed and that the equity market shaped price changes on the real estate market. The authors found a weak linear relationship and a non-linear relationship (OKUNEV et al., 2002). In the context of investment portfolio diversification, Liow showed positive relationships between the real estate 
market and the equity market, noting that this relationship can be used to make the composition of the investment portfolio more attractive (Liow, 2006). In subsequent studies, Okunev et al. pointed to a strong relationship between the real estate market and the stock market. The real estate market was represented by REITs and the stock market by S\&P500 (Ookunev et al., 2000). Lin and Lin conducted research on Asian markets in China, Hong Kong, Japan, Singapore, South Korea and Taiwan. They studied the co-integration of stock and real estate markets using the Johansen co-integration test. The research method was based on the previously cited studies of Okunev and Wilson (1997). Research indicates co-integration of markets in Japan and partial co-integration in China, Hong Kong and Taiwan. However, no relationship between markets was found in South Korea and Singapore. In addition, it was found that, in Taiwan and Singapore, this relationship was reversed compared to other economies and the stock market followed the real estate market. The authors point to the possibility of predicting the development of one market under the influence of another, which reduces investment risk by avoiding an oncoming crises (Lin \& Lin, 2011). Apergis and Lambrinidis conducted co-integration tests on stock and property markets in the United States and Great Britain. The research was conducted on quarterly data from the first quarter of 1985 to the second quarter of 2006. The authors showed that the two markets can be considered highly integrated (Apergis \& Lambrinidis, 2011). Xiaohui et al. showed that equity and real estate markets can be correlated to some extent, and co-integration analysis using tests such as the ADF test, co-integration test or Granger Causality test show that these markets are integrated (Xiaohui et al., 2012). Sing and Tan conducted research on six markets including the USA, Great Britain, Ireland, Australia, Hong Kong and Singapore. The study used the dynamic conditional correlation (DCC) model. Empirical results have shown a correlation between equity and real estate markets. In markets in Singapore and Hong Kong, as well as in the United States, correlations between markets increase in periods after a financial crises (Sing \& Tan, 2013). Lin and Fuerst performed a study on data from nine Asian countries from 1980 to 2012. The indices used were equity and real estate price indices using a linear and non-linear co-integration analysis. A relationship between the markets was found for Taiwan, and partial integration of the markets in Hong Kong and Singapore. In contrast, in China, Japan, Thailand, Malaysia, Indonesia and South Korea, no links were noted between the markets. Research shows that market integration is not related to the degree of economic development of the country, and Asian economies differ unexpectedly (Lin \& Fuerst, 2014).

Studies of the relationship between equity and real estate markets have been conducted in many countries and using different research methods. There are so many that quoting each of them seems unnecessary, especially in the context of the results obtained. Although they usually differ, they have one common denominator. Relationships between real estate investments and shares are being sought. (Liow et al., 2009; Heaney \& Sriananthakumar, 2012; Yang et al., 2012; Szumilo et al., 2018)

On the Polish market, research on the relationship between the stock market and the real estate market is not as common as on developed markets. Relations between different financial market segments have not always been demonstrated. Dyduch studied the long-term relationship between the stock market and the sovereign bond market using the co-integration analysis of the WIG index and the TBPS.Index index. The study conducted from February 2011 to February 2016, using EngleGranger analysis, did not indicate the existence of co-integrating relationships between the indices. Wolski (2018) conducted an analysis of the correlation between the stock and real estate market. The built model pointed to the existence of a relationship between markets, but no co-integration study was performed. A co-integration study affecting the real estate market was carried out by Batóg, examining a number of economic and financial factors, including the number of flats delivered. However, this analysis did not strictly concern the real estate market or the stock market (Batóg, 2016).

Table 1

Literature overview

\begin{tabular}{cl}
\hline Attribute & Designation \\
\hline Author/s & OKUNEV, WILSON 1997 \\
\hline Database & REIT i indeksu S\&P500 od stycznia 1973 do grudnia 1993. \\
\hline Market & USA \\
\hline Methodology & Linear and non-linear cointegration tests. \\
\hline
\end{tabular}




\begin{tabular}{|c|c|}
\hline Result & $\begin{array}{l}\text { The results of linear cointegration support the view that the real estate and stock } \\
\text { markets are segmented, whereas the nonlinear model supports the view that the } \\
\text { markets are fractionally integrated. }\end{array}$ \\
\hline Author/s & QUAN, TITMAN 1999 \\
\hline Database & $\begin{array}{l}\text { Capital values and rental indexes for real estate - weighted indexes of selected } \\
\text { stocks in each country, period1984-1996. }\end{array}$ \\
\hline Market & 17 countries from all over the World. \\
\hline Methodology & Cross-sectional regressions. \\
\hline Result & $\begin{array}{l}\text { Authors found significant positive relations between both real estate values and } \\
\text { rental rates and stock returns. }\end{array}$ \\
\hline Author/s & OKUNEV et al. 2000 \\
\hline Database & $\begin{array}{l}\text { US real estate (Equity REITs) and S\&P } 500 \text { stock markets between the years of } 1972 \\
\text { to } 1998 \text {. }\end{array}$ \\
\hline Market & USA \\
\hline Methodology & Linear and nonlinear causality tests. \\
\hline Result & $\begin{array}{l}\text { Linear test results show a uni-directional relationship existing from the real estate } \\
\text { market to the stock market. The nonlinear test shows a strong unidirectional } \\
\text { relationship running from the stock market to the real estate market. }\end{array}$ \\
\hline Author/s & OKUNEV et al. 2002 \\
\hline Database & $\begin{array}{l}\text { The time series used for the causality tests are weekly logarithmic returns from the } \\
\text { real estate index and the All-Ords stock index from January } 1980 \text { to August } 1999 .\end{array}$ \\
\hline Market & Australia \\
\hline Methodology & Linear and non-linear cointegration tests. \\
\hline Result & $\begin{array}{l}\text { Results of linear causality tests showed that stock market movements led to real } \\
\text { estate movements. The non-linear causality test showed a strong unidirectional } \\
\text { relationship running from the stock market to the real estate market. }\end{array}$ \\
\hline Author/s & LIOW 2006 \\
\hline Database & $\begin{array}{l}\text { Urban Redevelopment Authority's quarterly transaction-based residential (PPIR) } \\
\text { and office (PPIO) property price indices and Singapore Stock Exchange's Straits } \\
\text { Time Industrial Index (STI) and three common macroeconomic variables: gross } \\
\text { domestic product (GDP), prime leading rate (INT) and inflation. Logarytmic } \\
\text { quarterly rates of return were calculated in the period of the first quarter of } 1985 \\
\text { until the fourth quarter of } 2002 \text {. }\end{array}$ \\
\hline Market & Singapore \\
\hline Methotology & Autoregressive Distributed Lag (ARDL) cointegration procedure \\
\hline Result & $\begin{array}{l}\text { A long-run contemporaneous relationship is found between the stock and property } \\
\text { prices. }\end{array}$ \\
\hline Author/s & LIN, LIN 2011 \\
\hline Database & $\begin{array}{l}\text { The quarterly indices of the stock and real estate markets from March } 1995 \text { to June } \\
2010 \text {. }\end{array}$ \\
\hline Market & China, Hong Kong, Japan, Singapore, South Korea, and Taiwan \\
\hline Methodology & $\begin{array}{l}\text { Unit root test and cointegration tests (Johansen (1988) and Johansen and Juselius } \\
\text { (1990) cointegration approaches). }\end{array}$ \\
\hline Result & $\begin{array}{l}\text { Results show that stock markets are integrated with real estate markets in Japan, } \\
\text { and partially integrated with real estate markets in China, Hong Kong, and Taiwan. }\end{array}$ \\
\hline Author/s & APERGIS, LAMBRINIDIS 2011 \\
\hline Database & $\begin{array}{l}\text { Quarterly data on stock price indices (P) proxied by the Dow Jones index (DJ), the } \\
\text { S\&P } 500 \text { index (SP500), the NYSE index (NYSE) and the FTSE } 100 \text { index (FTSE) and } \\
\text { on physical real estate (unsecuritized) prices (RE) measured by the Federal Housing } \\
\text { Enterprise Oversight index for the US (REUS) and the Halifax Index for the UK } \\
\text { (REUK) were obtained from the Bloomberg data base from the first quarter of } 1985 \\
\text { to the second quarter of } 2006 \text {. }\end{array}$ \\
\hline Market & UK and USA \\
\hline
\end{tabular}




\section{$\$$ sciendo}

\begin{tabular}{|c|c|}
\hline Methodology & Cointegration (Johansen and Juselius (1990)) and Error Correction modeling. \\
\hline Result & The two markets are considered highly integrated. \\
\hline Author/s & XIAOHUI et al. 2012 \\
\hline Database & $\begin{array}{l}\text { The monthly data of Chinese Real Estate Sales Price Index (CRPI) is selected to } \\
\text { analyze Chinese real estate fluctuating cycles. Data is from the China Economic } \\
\text { Information Network Statistics Database. Shanghai Composite Index HCPI and } \\
\text { Shenzhen Component Index SCPI are chosen as the indexes to measure price } \\
\text { changes in the Chinese stock market. HCPI and SCPI are published by Shanghai } \\
\text { Stock Exchange and Shenzhen Stock Exchange. Data from January } 1999 \text { to April } \\
\text { 2005, May } 2005 \text { to January 2008, and March 2008 to October } 2009\end{array}$ \\
\hline Market & China \\
\hline Methodology & ADF test, co-integration test, and Granger Causality test. \\
\hline Result & The Chinese real estate market and the stock market are integrated. \\
\hline Author/s & FOO SING, YAO TAN 2013 \\
\hline Database & $\begin{array}{l}\text { Time-series data on direct real estate and general stocks. The data are on a quarterly } \\
\text { basis. Stock and direct real estate quarterly returns were calculated. Research period } \\
\text { vary depending on the market. The longest research period for the USA covers } \\
\text { 4Q1977-2Q2008, and shortest for Ireland covers 1Q1990 - 1Q2008. }\end{array}$ \\
\hline Market & USA, UK, Ireland, Australia, Hong Kong and Singapore \\
\hline Methodology & $\begin{array}{l}\text { Dynamic conditional correlation (DCC) model testing the time-varying correlations } \\
\text { between stock and direct real estate returns. }\end{array}$ \\
\hline Result & $\begin{array}{l}\text { The empirical results show significant time-varying effects in the conditional } \\
\text { covariance between stock returns and direct real estate returns. }\end{array}$ \\
\hline Author/s & LIN, FUERST 2014 \\
\hline Database & $\begin{array}{l}\text { Quarterly transaction-based housing price index published by Oxford Economics } \\
\text { from the period January } 1980 \text { to September } 2012 \text { The stock market indices employed } \\
\text { are the main stock indices from analyzed countries. }\end{array}$ \\
\hline Market & $\begin{array}{l}\text { Taiwan, Singapore, Hong Kong, China, Japan, Thailand, Malaysia, Indonesia and } \\
\text { South Korea }\end{array}$ \\
\hline Methodology & $\begin{array}{l}\text { Linear and nonlinear cointegration techniques (Johansen and Gregory-Hansen } \\
\text { cointegration testing). }\end{array}$ \\
\hline Result & $\begin{array}{l}\text { Evidence of linear cointegration of stock and property markets were found in } \\
\text { Taiwan, fractional cointegration in Singapore and Hong Kong and no evidence of } \\
\text { cointegration in China, Japan, Thailand, Malaysia, Indonesia and South Korea. }\end{array}$ \\
\hline Author/s & WOLSKI 2018 \\
\hline Database & $\begin{array}{l}\text { The quarterly rates of returns on NBP housing real estate prices hedonic indices and } \\
\text { Warsaw Exchange Indices and developer companies' quotations were used. The } \\
\text { study was carried out from the first quarter of } 2011 \text { to the third quarter of } 2017 .\end{array}$ \\
\hline Market & Poland \\
\hline Methodology & Cross-sectional regression analysis. \\
\hline Result & The real estate market and the stock market of real estate companies are interrelated. \\
\hline
\end{tabular}

Source: own study based on cited literature.

Although studies of the relationship between shares and real estate are not very widespread, other studies dealing with the issue of price relationships and the rate of return on real estate with other economic factors, or the impact of specific factors on real estate prices, are quite widespread (Żelazowski, 2011; Trojanek, 2012; Bełeł \& Kulesza, 2015; Dittmann, 2016; Kubus, 2016; Foryś \& Tarczyńska-Łuniewska, 2017; Wolski 2017).

\section{Evidence on real estate and stock markets}

In the light of research conducted so far, it seems that the application of co-integration analysis between stock market indices and average prices on the secondary housing market is a direction that allows for better verification of the hypothesis regarding the relationship between these markets. Therefore, the author set the purpose of the work: to verify whether there is co-integration between 
the secondary housing market and the stock market. A research hypothesis was put forward: the stock market and secondary housing market are integrated.

\subsection{Data}

For the analysis, both data from the secondary housing market, represented by the average of prices calculated by the National Bank of Poland for 7 cities (Gdansk, Gdynia, Lodz, Krakow, Poznan, Warsaw, Wroclaw) - marked with the abbreviation cities in the study, for 10 cities (Bialystok, Bydgoszcz, Katowice, Kielce, Lublin, Olsztyn, Opole, Rzeszow, Szczecin, Zielona Gora) - marked in the study as cities1 and for 6 Polish cities (Gdansk, Gdynia, Lodz, Krakow, Poznan, Wroclaw) marked in the study as cities2, as well as data from the Warsaw Stock Exchange were used. Stock market data included WIG, WIG20, WIG Real Estate indexes - marked in the survey as WIGN and WIG Contraction marked in the survey as WIGB. The collected data covered the period from the third quarter of 2006 to the fourth quarter of 2018.

\subsection{Methodology}

The study used co-integration analysis. The Engle-Granger test was used to test the relationship between subsequent real estate and stock market indices. First, the available time series were analyzed, calculating descriptive statistics such as mean, median, coefficient of variation, skewness and kurtosis for all data. The minimum and maximum value was indicated in each of the time series of quotations from the real estate and stock market. Four tests for distribution normality were carried out: Doornik-Hansen, Shapiro-Wilk, Lilliefors and Jarque-Ber tests. The tested co-integration equations did not use a delay of explanatory variables. The variables explained in these equations were the subsequent average prices of residential real estate on the secondary market in Poland: for 7 , 10 and 6 cities (cities, cities1 and cities2). The choice of such and other data for the study results directly from the methodology for creating the property price database by the National Bank of Poland.

\subsection{Research results}

Data analysis began with the calculation of descriptive statistics of the data series of subsequent indices and averages. It is worth noting at this point that the analysis of descriptive statistics for time series of quotations does not carry too much information. This is, first of all, because the average price for a period of less than 13 years does not reflect any market processes. It is similar with the median. But the analysis of extreme, minimum and maximum values gives an idea of the behavior of the market during the period considered. Attention is drawn here to the values of the stock indexes: WIG Real Estate (WIGN), WIG Construction (WIGB), or WIG. The maximum value is over five times higher than the minimum value in the case of the WIGN index, more than seven times higher for the WIGB, almost three times higher for the WIG index and so, for the WIG20 index, the maximum value is about 2.5 times the minimum value. For average prices of cities, this ratio is 1.50, for cities1 1.79 times, and for cities2, it is 1.66 times. These differences in the level of minimum and maximum prices are clearly reflected in standard deviations. However, in the case of quotations, standard deviations are hard to compare because they are calculated in the same units. However, one can notice a tendency that, where the differences in the minimum and maximum rates were a large multiple, the standard deviations were significant. And so for WIGN, this was 1285.1, for WIGB 2528, and for WIG 9165.8. In this context, the coefficient of variation is useful, as its values are high for stock indices in comparison with average housing prices. Analyzing the distribution of quotations, one can observe lefthandedness for average housing prices and the WIG index, and right-handedness for other stock indices. For average prices of cities and the WIG index, the value of kurtosis is close to zero, which allows the charts to be almost mesocurtic. The value of kurtosis in other cases is positive and high enough to talk about leptopkutic distributions.

The values of descriptive statistics are presented in Table 2 .

Descriptive statistics for original data for the period from 3Q 2006 to 4Q 2018

Table 2

\begin{tabular}{l|rrcr}
\hline Variable & \multicolumn{1}{c}{ Mean } & Median & Min & \multicolumn{2}{c}{ Max } & \\
\hline cities & 6150.80 & 6195.10 & 4648.70 & 6965.50 \\
\hline
\end{tabular}




\begin{tabular}{l|rrrr}
\hline cities1 & 3981.90 & 4030.20 & 2595.40 & 4643.90 \\
\hline cities2 & 5220.30 & 5258.80 & 3713.00 & 6150.80 \\
\hline WIGN & 2320.70 & 1922.50 & 1236.70 & 6463.10 \\
\hline WIGB & 4092.50 & 2921.40 & 1602.20 & 11686.00 \\
\hline WIG20 & 2426.20 & 2370.70 & 1511.80 & 3759.30 \\
\hline WIG & 48342.00 & 48572.00 & 24036.00 & 66078.00 \\
\hline Variable & Stand.dev. & C.V. & Skewness & Ex. Kurtosis \\
\hline cities & 501.99 & 0.08 & -0.30 & -0.09 \\
\hline cities1 & 343.53 & 0.09 & -1.82 & 5.48 \\
\hline cities2 & 439.56 & 0.08 & -0.53 & 1.26 \\
\hline WIGN & 1285.10 & 0.55 & 1.71 & 2.12 \\
\hline WIGB & 2528.00 & 0.62 & 1.35 & 1.13 \\
\hline WIG20 & 479.11 & 0.20 & 0.97 & 1.06 \\
\hline WIG & 9165.8 & 0.19 & -0.37 & 0.09 \\
\hline
\end{tabular}

Source: own study.

The chart presents a graphical record of the value of the quotations studied over time for the entire period from the third quarter of 2006 to the fourth quarter of 2018.
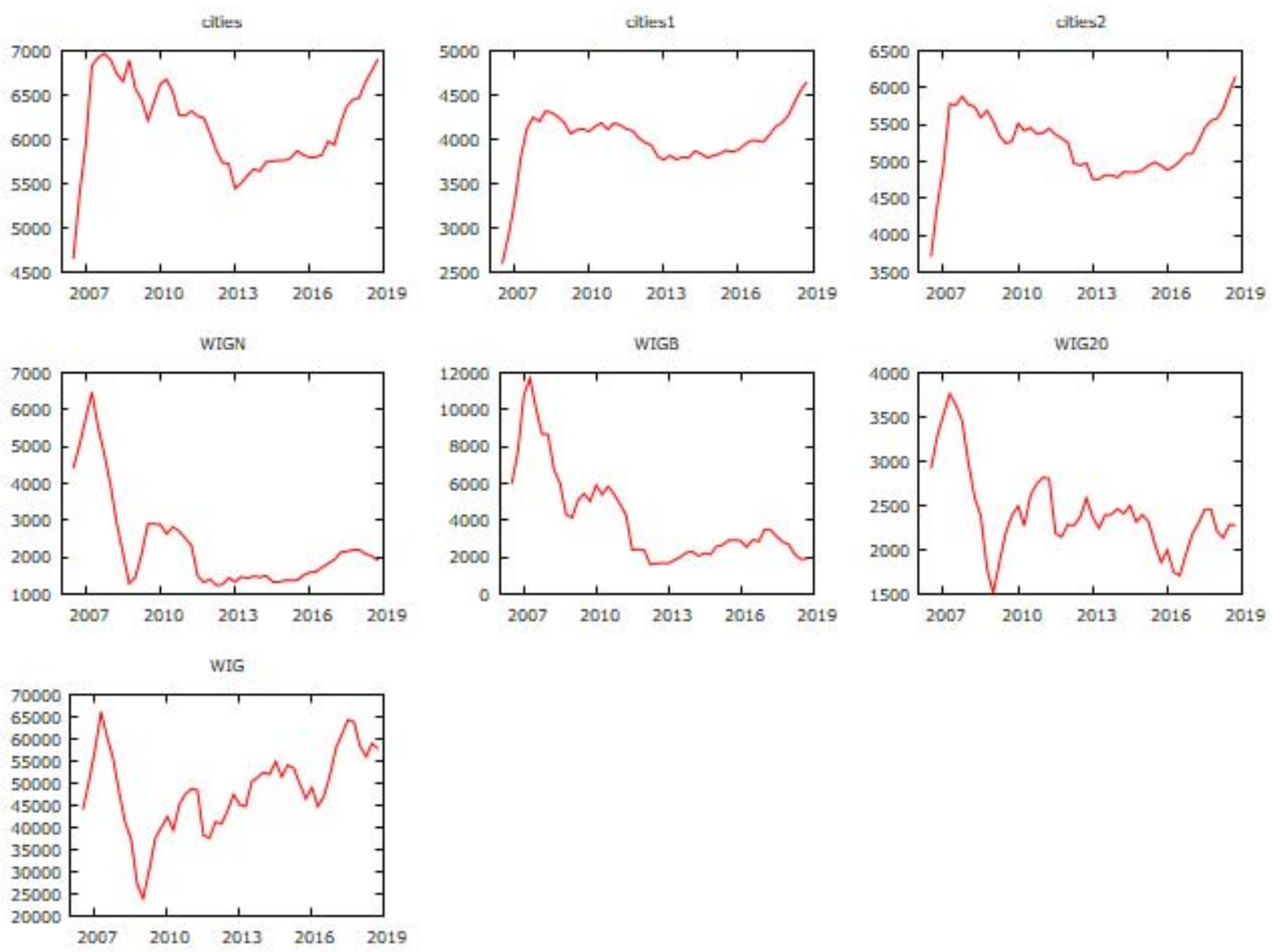

Fig. 1. Analyzed quotations from 3Q 2006 to 4Q 2018. Source: own study.

The analysis of descriptive statistics indicates a higher volatility of stock indices than average real estate prices. This translates into higher risk associated with investment in shares. In addition, the analysis of quotations charts over the period under consideration makes it possible to highlight the achievable returns on investment in the equity and housing market. Of the WIG indices, only WIG approached the levels recorded in 2007-2008, although it did not reach levels from the beginning of 
the research period in the fourth quarter of 2018. Meanwhile, average real estate prices remain at a similar (cities) or higher level (cities1 and cities2) than at the beginning of the observation period. For courses, left-handedness of distribution would be a desirable feature. It would mean the dominance of high prices. However, right-handedness dominates in the studied prices. This means that low rates outweigh the limit of potential investors' profits.

In the next step of the data analysis, the normality of the distribution of the observed courses was verified. Normal distribution of quotations was not expected, mainly due to the nature of the listed assets. A normal distribution would mean no profit potential, since extreme values, including high rates, would constitute a minority of all quotations. The kurtosis analysis presented in the previous table supplements the distribution analysis. Therefore, if the distribution were to not be a normal distribution, and in addition were a left-sided distribution, then the investors' profit would be more likely. The results of tests for normality have been presented in Table 3.

Table 3

Test for normality of subsequent analyzed indices

\begin{tabular}{|c|c|c|c|c|c|c|c|}
\hline Test & cities & cities1 & cities2 & WIGN & WIGB & WIG20 & WIG \\
\hline Doornika-Hansena & 0.94 & $20.21^{* * *}$ & $5.92^{*}$ & $57.43^{* * *}$ & $31.02^{* * *}$ & $8.47^{* *}$ & 1.52 \\
\hline Shapiro-Wilka & $0.95^{* *}$ & $0.83^{* * *}$ & $0.95^{* *}$ & $0.76^{* * *}$ & $0.83^{* * *}$ & $0.91^{* * *}$ & 0.98 \\
\hline Lillieforsa & 0.11 & $0.21^{* * *}$ & 0.11 & $0.22^{* * *}$ & $0.21^{* * *}$ & $0.18^{* * *}$ & 0.06 \\
\hline Jarque'a-Bera & 0.76 & $90.14^{* * *}$ & $5.63^{*}$ & $33.72 * * *$ & $17.93^{* * *}$ & $10.24^{* * *}$ & 1.18 \\
\hline
\end{tabular}

*** Significant at 0.01 (2-tailed significance).

** Significant at 0.05 (2-tailed significance).

* Significant at 0.1 (2-tailed significance).

Source: own study.

The tests conducted, in the vast majority, indicate the lack of normal distribution of stock indices and average prices of flats on the secondary market. Each time, the null hypothesis regarding the existence of a normal distribution was tested against the alternative hypothesis about the lack of normal distribution of data. In the case of cities, all tests except the Shapiro-Wilk test did not allow for the rejection of the null hypothesis with a normal distribution of courses. For cities1, the null hypothesis with a normal distribution at a high level of significance 0.01 was rejected. In the case of cities 2, only the Lilliefors test did not allow for the adoption of an alternative hypothesis regarding the lack of a normal distribution, although the other tests allowed the adoption of an alternative hypothesis at significance levels from 0.05 to 0.1 , which is a very liberal level. For the WIGN, WIGB and WIG20 indices, the null hypotheses about the existence of a normal distribution in all tests at a strict significance level of 0.01 were rejected. The exception was the Doornik-Hansen test for WIG20, where an alternative hypothesis at the significance level of 0.05 was adopted. For the WIG index, the normal distribution hypothesis was not rejected in any of the tests.

A total of 12 co-integration equations were built. Each time the dependent variables were average prices on the secondary housing market and independent variables were prices of stock price indices. The coefficients of the equations along with the basic indicators are shown in Table 4.

Table 4

Cointegrating regression - OLS, using observations 3Q 2006 - 4Q $2018(T=50)$

\begin{tabular}{ll|rrrr}
\hline $\begin{array}{c}\text { Dependent } \\
\text { variable }\end{array}$ & \multicolumn{1}{c}{$\begin{array}{c}\text { Delayed (4) } \\
\text { variable }\end{array}$} & Coefficient & Std. error & t-ratio & p-value \\
\hline cities & const & 5905.15 & 143.63 & 41.11 & $0.00^{* * *}$ \\
\hline & WIGN & 0.11 & 0.05 & 1.95 & $0.06^{*}$ \\
\hline const & 5821.94 & 125.73 & 46.30 & $0.00^{* * *}$ \\
\hline WIGB & 0.08 & 0.03 & 3.07 & $0.00^{* * *}$ \\
\hline const & 5827.08 & 370.82 & 15.71 & $0.00^{* * *}$ \\
\hline WIG20 & 0.13 & 0.15 & 0.89 & 0.38 \\
\hline & const & 6162.23 & 388.82 & 15.85 & $0.00^{* * *}$ \\
\hline
\end{tabular}




\begin{tabular}{ll|rrrr}
\hline & WIG & 0.00 & 0.01 & -0.03 & 0.98 \\
\hline cities1 & const & 4159.84 & 97.82 & 42.53 & $0.00^{* * *}$ \\
\hline & WIGN & -0.08 & 0.04 & -2.08 & $0.04^{* *}$ \\
\hline & const & 4072.72 & 92.83 & 43.88 & $0.00^{* * *}$ \\
\hline WIGB & -0.02 & 0.02 & -1.15 & 0.26 \\
\hline & const & 4508.52 & 243.84 & 18.49 & $0.00^{* * *}$ \\
\hline & WIG20 & -0.22 & 0.10 & -2.20 & $0.03^{* *}$ \\
\hline const & 4065.02 & 265.80 & 15.29 & $0.00^{* * *}$ \\
\hline Cities2 & WIG & 0.00 & 0.01 & -0.32 & 0.75 \\
\hline & const & 5091.38 & 128.92 & 39.49 & $0.00^{* * *}$ \\
\hline WIGN & 0.06 & 0.05 & 1.14 & 0.26 \\
\hline const & 5031.56 & 0116.079 & 43.35 & $0.00^{* * *}$ \\
\hline WIGB & 0.05 & 0.02 & 1.91 & $0.06^{*}$ \\
\hline const & 5055.51 & 326.46 & 15.49 & $0.00^{* * *}$ \\
\hline WIG20 & 0.07 & 0.13 & 0.51 & 0.61 \\
\hline Const & 5042.19 & 339.45 & 14.85 & $0.00^{* * *}$ \\
\hline WIG & 0.00 & 0.01 & 0.53 & 0.60 \\
\hline
\end{tabular}

*** Significant at 0.01 (2-tailed significance).

** Significant at 0.05 (2-tailed significance)

* Significant at 0.1 (2-tailed significance).

Source: own study.

Co-integration equations were used in tests performed using the Engle-Granger method. According to the methodology of this test, co-integration occurs, if a null hypothesis used for each process is not rejected, the unit-root hypothesis is rejected for the residuals (uhat) from the cointegrating regression.

Table 5

Cointegration test for stocks and real estate, test with constant

\begin{tabular}{|c|c|c|c|c|c|c|c|c|c|c|c|c|}
\hline $\begin{array}{l}\text { Augmente } \\
\text { d Dickey- } \\
\text { Fuller test } \\
\text { for }\end{array}$ & cities & cities & cities & cities & cities1 & cities1 & cities1 & cities1 & $\begin{array}{c}\text { cities } \\
2\end{array}$ & $\begin{array}{c}\text { cities } \\
2\end{array}$ & $\begin{array}{c}\text { cities } \\
2\end{array}$ & $\begin{array}{c}\text { cities } \\
2\end{array}$ \\
\hline $\begin{array}{l}\text { Test } \\
\text { statistictau } \\
\text { c(1): }\end{array}$ & -2.88 & -2.88 & -2.88 & -2.88 & -4.75 & -4.75 & -4.75 & -4.75 & -3.11 & -3.11 & -3.11 & -3.11 \\
\hline $\begin{array}{l}\text { Asymptoti } \\
\text { c p-value: }\end{array}$ & 0.06 & 0.06 & 0.06 & 0.06 & 0.00 & 0.00 & 0.00 & 0.00 & 0.03 & 0.03 & 0.03 & 0.03 \\
\hline $\begin{array}{l}\text { Augmente } \\
\text { d Dickey- } \\
\text { Fuller test } \\
\text { for: }\end{array}$ & $\begin{array}{l}\text { WIG } \\
\mathrm{N}\end{array}$ & WIGB & $\begin{array}{c}\text { WIG2 } \\
0\end{array}$ & WIG & $\begin{array}{l}\text { WIG } \\
\mathrm{N}\end{array}$ & WIGB & $\begin{array}{c}\text { WIG2 } \\
0\end{array}$ & WIG & $\begin{array}{l}\text { WIG } \\
\mathrm{N}\end{array}$ & $\begin{array}{l}\text { WIG } \\
\text { B }\end{array}$ & $\begin{array}{c}\text { WIG2 } \\
0\end{array}$ & WIG \\
\hline $\begin{array}{l}\text { Test } \\
\text { statistictau } \\
\text { c(1): }\end{array}$ & -1.71 & -1.11 & -1.87 & -1.62 & -1.71 & -1.11 & -1.87 & -1.62 & -1.71 & -1.11 & -1.87 & -1.62 \\
\hline $\begin{array}{l}\text { Asymptoti } \\
\text { c p-value: }\end{array}$ & 0.42 & 0.71 & 0.34 & 0.46 & 0.42 & 0.71 & 0.34 & 0.46 & 0.42 & 0.71 & 0.34 & 0.46 \\
\hline \multicolumn{13}{|c|}{ Augmented Dickey-Fuller test for uhat (residual process) } \\
\hline $\begin{array}{l}\text { Test } \\
\text { statistictau } \\
\text { cc(1): }\end{array}$ & -3.63 & -3.45 & -3.06 & -2.90 & -3.76 & -4.42 & -4.08 & -4.57 & -3.55 & -3.39 & -3.22 & -3.12 \\
\hline Asymptoti & 0.03 & 0.05 & 0.11 & 0.16 & 0.03 & 0.00 & 0.01 & 0.00 & 0.04 & 0.06 & 0.08 & 0.10 \\
\hline
\end{tabular}




\begin{tabular}{|c|c|c|c|c|c|c|c|c|c|c|c|c|}
\hline с p-value: & & & & & & & & & & & & \\
\hline $\begin{array}{l}\text { Sample } \\
\text { size: }\end{array}$ & 49 & 49 & 49 & 49 & 49 & 49 & 49 & 49 & 49 & 49 & 49 & 49 \\
\hline $\begin{array}{l}\text { Significanc } \\
\text { e level } 0.01\end{array}$ & $\mathrm{~N}$ & $\mathrm{~N}$ & $\mathrm{~N}$ & $\mathrm{~N}$ & $\mathrm{~N}$ & $\mathrm{~N}$ & $\mathrm{~N}$ & $\mathrm{~N}$ & $\mathrm{~N}$ & $\mathrm{~N}$ & $\mathrm{~N}$ & $\mathrm{~N}$ \\
\hline $\begin{array}{l}\text { Significanc } \\
\text { e level } 0,05\end{array}$ & $Y$ & $\mathrm{~N}$ & $\mathrm{~N}$ & $\mathrm{~N}$ & $\mathrm{~N}$ & $\mathrm{~N}$ & $\mathrm{~N}$ & $\mathrm{~N}$ & $\mathrm{~N}$ & $\mathrm{~N}$ & $\mathrm{~N}$ & $\mathrm{~N}$ \\
\hline $\begin{array}{l}\text { Significanc } \\
\text { e level } 0,1\end{array}$ & $\mathrm{~N}$ & $\mathrm{~N}$ & $\mathrm{~N}$ & $\mathrm{~N}$ & $\mathrm{~N}$ & $\mathrm{~N}$ & $\mathrm{~N}$ & $\mathrm{~N}$ & $\mathrm{~N}$ & $\mathrm{~N}$ & $\mathrm{~N}$ & $\mathrm{~N}$ \\
\hline
\end{tabular}

co-integration occurs: $\mathrm{Y}$, co-integration does not occur: $\mathrm{N}$.

There is evidence for a co-integrating relationship if:

(a) The unit-root hypothesis is not rejected for the individual variables, and

(b) the unit-root hypothesis is rejected for the residuals (uhat) from the co-integrating regression.

\section{Source: own study.}

Co-integration analysis was also carried out for the delayed explanatory variable, but in none of the six cases, with delays of 1 to 6 periods, was any evidence or co-integration found. In one case, where independent variables were not delayed, evidence for co-integration was detected. The average housing prices on the secondary market cities and WIG Real Estate were integrated at a significance level of 0.05 . No significance of co-integration was found for the remaining variables. In all other cases and for all levels of significance, co-integration could not be identified, regardless of which of the three levels of significance were considered.

To sum up the tests for co-integration, it should be noted that co-integration was found in one case out of thirty-six, with the non-delayed explanatory variable. Similarly, there was no evidence for cointegration in 35 cases.

The study does not provide grounds for drawing unequivocal conclusions. It is difficult to consider the null hypothesis on the integration of real estate and stock markets as positively verified; however, the study showed that there is a part of the market that can be considered integrated. It seems legitimate in this situation to state that the housing and equity markets are partially integrated in Poland. Although it was possible to find co-integration relations in only in one case, it should be noted that the explanatory variable was the average price on the secondary housing market for the 7 largest Polish cities. This makes it an important indicator - even by the number of inhabitants residing in the cities included in the index (according to the Central Statistical Office of Poland data from 2018, 5114 663 people live in these cities, which constitutes $13.31 \%$ of the Polish population). On the other hand, the explained variable was the WIG Real Estate index - an index reflecting the situation on the part of the stock market where real estate companies operate. This result can be seen as a harbinger of market development and perhaps, in the future, co-integration of stock and real estate markets will be more easily observable.

\section{Conclusions}

The conducted research did not allow to unambiguously verify the research hypothesis. A total of 36 tests were carried out using the Engle - Granger method with the use of the not delayed explanatory variable. Co-integration with a significance level of 0.05 was demonstrated in one case out of thirtysix. This means that the real estate and stock market are only partially integrated in Poland. The tests were performed using independent variables: WIG, WIG20, WIG Real Estate and WIG Construction indices. The dependent variables were the average prices of residential real estate on the secondary market in 7, 10 and 6 cities in Poland. The entire study period available for real estate prices was used for the study. As shown in Figure 1, the research period covered a period of very dynamic market changes. Finding one case of market integration shows the need for further research. First of all, the selection of a different research period should be considered. This is justified by the fact that, due to the relatively short research period, any anomaly on the market may have an unreasonably large impact on the results of the study. 


\section{References}

Apergis, N., \& Lambrinidis, L. (2011). More evidence on the relationship between the stock and the real estate market. Briefing Notes in Economics, 85, 1-11.

Batóg, B. (2016). Badanie kointegracji wybranych zmiennych ekonomiczno-finansowych w województwie zachodniopomorskim. Studia i Prace WNEiZ US, (45/2), 133-141.

Bełej, M., Kulesza, S. (2015). The Dynamics Of Time Series Of Real Estate Prices. Real Estate Management and Valuation, 23(4), 35-43. https://doi.org/10.1515/remav-2015-0034.

Clayton, J., Gordon, J. N., Fabozzi, J. F., Giliberto, S. M., Liang, Y., \& Hudson-Wilson, S. (2007). Real Estate Comes of Age. Journal of Portfolio Management, 33(5), 15-26. https://doi.org/10.3905/jpm.2007.698955.

Coşkun, Y. (2013). Housing-construction market risks in Turkey: overrated or underestimated? Housing Finance International, 27(3), 46-54.

Dittmann, I. (2016). Rates of Return on Shares of Real Estate Development Companies in Poland in the Years 2001-2015. A Comparative Analysis. Real Estate Management and Valuation, 24(4), 23-34. https://doi.org/10.1515/remav-2016-0027.

Dyduch, J. (2016). Analiza zależności długookresowych między indeksem WIG i indeksem obligacji skarbowych TBSP. Index. Studia Ekonomiczne, 282, 26-34.

Foryś, I. (2012). Metoda mix-adjustment wyznaczania indeksów cen nieruchomości mieszkaniowych na przykładzie lokali spółdzielczych, (Mix-Adjustment Method Used to Construct the Residental House Price Indices on the Example of Cooperative Housing), red. nauk. Źróbek, S., Studia $i$ Materiały Towarzystwa Naukowego Nieruchomości, 20(1), 41-52.

Foryś, I., \& Tarczyńska-Łuniewska, M. (2017). Polish Real Estate Funds and International Experience. Acta Scientiarum Polonorum. Oeconomia, 16(2), 45-53. https:// doi.org/10.22630/ ASPE.2017.16.2.17.

Główny Urzą, Statystyczny (Statistics Poland), https://stat.gov.pl/en/, date of acces:11-08-2019.

Heaney, R., \& Sriananthakumar, S. (2012). Time-varying correlation between stock market returns and real estate returns. Journal of Empirical Finance, 19(4), 583-594. https:// doi.org/10.1016/j.jempfin.2012.03.006.

Jensen, M. C. (1968). The Performance of Mutual Funds in the Period 1945-1964. The Journal of Finance, 23(2), 389-416. https:// doi.org/10.1111/j.1540-6261.1968.tb00815.x.

Liow, K. H. (2006). Dynamic relationship between stock and property markets [serial online]. Applied Financial Economics, 16(5), 371-376. https:/ / doi.org/10.1080/09603100500390885.

Liow, K. H., Ho, K. H. D., Ibrahim, M. F., \& Chen, Z. (2009). Correlation and Volatility Dynamics in International Real Estate Securities Markets. The Journal of Real Estate Finance and Economics, 39(2), 202-223. https://doi.org/10.1007/s11146-008-9108-4.

Kubus, M. (2016). Assessment of Predictor Importance with the Example of the Real Estate Market. Folia Oeconomica Stetinensia, 16(2), 29-39. https:// doi.org/10.1515/foli-2016-0023.

Lin, P., \& Fuerst, F. (2014). The integration of direct real estate and stock markets in Asia. Applied Economics, 46(12), 1323-1334. https:/ / doi.org/10.1080/00036846.2013.872763.

Lin, T. C., \& Lin, Z.-H. (2011). Are stock and real estate markets integrated? An empirical study of six Asian economies. Pacific-Basin Finance Journal, 19(5), 571-585. https://doi.org/10.1016/ j.pacfin.2011.05.001.

Maclennan, D., Muellbauer, J., \& Stephens, M. (1998). Asymmetries in housing and financial market institutions and EMU. Oxford Review of Economic Policy, 14(3), 54-80. https://doi.org/10.1093/ oxrep/14.3.54.

Okunev, J., \& Wilson, P. J. (1997). Using nonlinear tests to examine integration between real estate and stock markets. Real Estate Economics, 25(3), 487-503. https:// doi.org/10.1111/1540-6229.00724.

Okunev, J., Wilson, P., \& Zurbruegg, R. (2000). The Causal Relationship Between Real Estate and Stock Markets. The Journal of Real Estate Finance and Economics, 21(3), 251-261. https://doi.org/10.1023/A:1012051719424.

Okunev, J., Wilson, P., \& Zurbruegg, R. (2002). Relationships between Australian Real Estate and Stock Market Prices-A Case of Market Inefficiency. Journal of Forecasting, 21(3), 181-192. https://doi.org/10.1002/for.825.

Quan, D. C., \& Titman, S. (1999). Do Real Estate Prices and Stock Prices Move Together? An International Analysis. Real Estate Economics, 27(2), 183-207. https://doi.org/10.1111/15406229.00771 . 
Foo Sing, T., \& Yao Tan, Z. (2013). Time-varying correlations between stock and direct real estate returns. Journal of Property Investment $\mathcal{E}$ Finance, 31(2), 179-195. https://doi.org/10.1108/ 14635781311302591.

Szumilo, N., Wiegelmann, T., Łaszkiewicz, E., Pietrzak, M. B., \& Balcerzak, A. P. (2018). The Real Alternative? A Comparison Of German Real Estate Returns With Bonds And Stocks. Journal of Property Investment E Finance, 36(1), 19-31. https:/ / doi.org/10.1108/JPIF-02-2017-0012.

Trojanek, R. (2012). An Analysis Of Changes In Dwelling Prices In The Biggest Cities Of Poland In 2008-2012 Conducted With The Application Of The Hedonic Method, Actual Problems of Economics, pp. 5-VOICU, C., SEILER, M. J., 2013, Understanding Systematic Risk in Real Estate Markets. Journal of Housing Research, 22(2), 165-201.

Wilson, P. I., Okunev, J., \& Ta, G. (1996). Are real estate and securities markets integrated: Some Australian evidence. Journal of Property Valuation and Investment, 14(5), 7-24. https:/ / doi.org/10.1108/14635789610154253.

Wolski, R. (2014). Application Of Beta Coefficient In The Market Of Direct Residential Real Estate Investments. Real Estate Management and Valuation, 22(2), 13-21. https://doi.org/10.2478/remav2014-0013.

Wolski, R. (2017). Risk And Return In The Real Estate, Bond And Stock Markets. Real Estate Management and Valuation, 25(3), 15-22. https:/ / doi.org/10.1515/remav-2017-0018.

Wolski, R. (2018). Listing of Developer Companies as a Predictor of the Situation on the Residential Real Estate Market. Real Estate Management and Valuation, 26(4), 12-21. https:/ / doi.org/10.2478/remav-2018-0032.

Wolski, R., Załęczna, M. (2013). The Atracttiveness of Real Estate Investment in Polish Conditions, Real Estate Management and Valuation, 21(3), https:/ / doi.org/10.2478/remav-2013-0027, pp. 62-70.

Xiaohui, G., Jingyi, L., \& Gu, A. Y. (2012). The Relatinship Between Real Estate Market and Stock Market. Journal Of. International Business Research, 11(1), 73-79.

Yang, J., Zhou, Y., \& Leung, W. (2012). Asymmetric Correlation and Volatility Dynamics among Stock, Bond, and Securitized Real Estate Markets. The Journal of Real Estate Finance and Economics, 45(2), 491-521. https:/ / doi.org/10.1007/s11146-010-9265-0

Żelazowski, K. (2011). Regionalne zróżnicowanie cen i ich determinant na rynku mieszkaniowym w Polsce (Regional Differences in Prices and Their Determinants on Polish Housing Market), Studia $i$ Materiały Towarzystwa Naukowego Nieruchomości, 19(3), 98-106. 